\title{
Spain, Land of Refuge and Survival for Thousands of Muslims: Sixteenth to Eighteenth Centuries
}

We have already described how Moriscos and slaves have attracted the greatest attention from historians, who have barely begun to turn to the many, previously neglected free Muslims living in Spain: exiles, merchants, adventurers, military men, spies, converts, and others. ${ }^{1}$ The eighteenth century has received the least scrutiny, since the Morisco period was over and Muslim slavery gradually disappeared after the Spanish monarchy signed treaties of peace, friendship, and trade with the Sultan of Morocco, the Dey of Algiers, the Beys of Tunis and Tripoli, and the Ottoman Caliph. The growing number of Muslims who came to Spain after the establishment of peaceful relations has largely been ignored.

We have also observed that the maritime frontier between Spain and Muslim lands should not be called "forgotten," since it was always being crossed; indeed, like all borders, it was always porous. ${ }^{2}$ It was certainly never forgotten by all the Muslims who sought refuge in Spain for shorter or longer periods. A notable group were the exiles from royal families who had lost their thrones and who traveled with their trains of relatives and partisans (see Chapter 2). Others were fleeing the authorities in their homelands, sometimes for having converted to Christianity or committed serious crimes such as homicides. Many more were refugees from the frequent famines in the region, preferring slavery in a Christian country to death by starvation in their own.

In the following Map 1 we have located the geographical points in Spain where Muslims have been identified during the long age of hostility from 1492

1 The exception is B. Vincent: "Exilio interior y refugio internacional," "Les musulmans dans l'Espagne moderne," and "L'Islam en Espagne à l'époque moderne."

2 We should also pay attention to the Spanish presidios on the North African coast: Oran, Mazalquivir, Ceuta, Melilla, Peñón de Vélez de la Gomera, Peñón de Alhucemas, and many other coastal towns and areas that fell under Spanish rule between 1497 and 1551 before being retaken by Muslims. Spanish garrisons quartered there forged relationships with residents of the towns and the nearby hinterlands. While this issue goes beyond the scope of our study, see for the general context Alonso Acero, España y el Norte de África, and García-Arenal and Bunes Ibarra, Los españoles y el Norte de África. On specific presidios: Fe Cantó, "Oran (1732-1745)"; Alonso Acero, Orán-Mazalquivir; Schaub, Les juifs du roi d'Espagne. Oran; García Figueras and Rodríguez Joulia Saint-Cyr, Larache. 


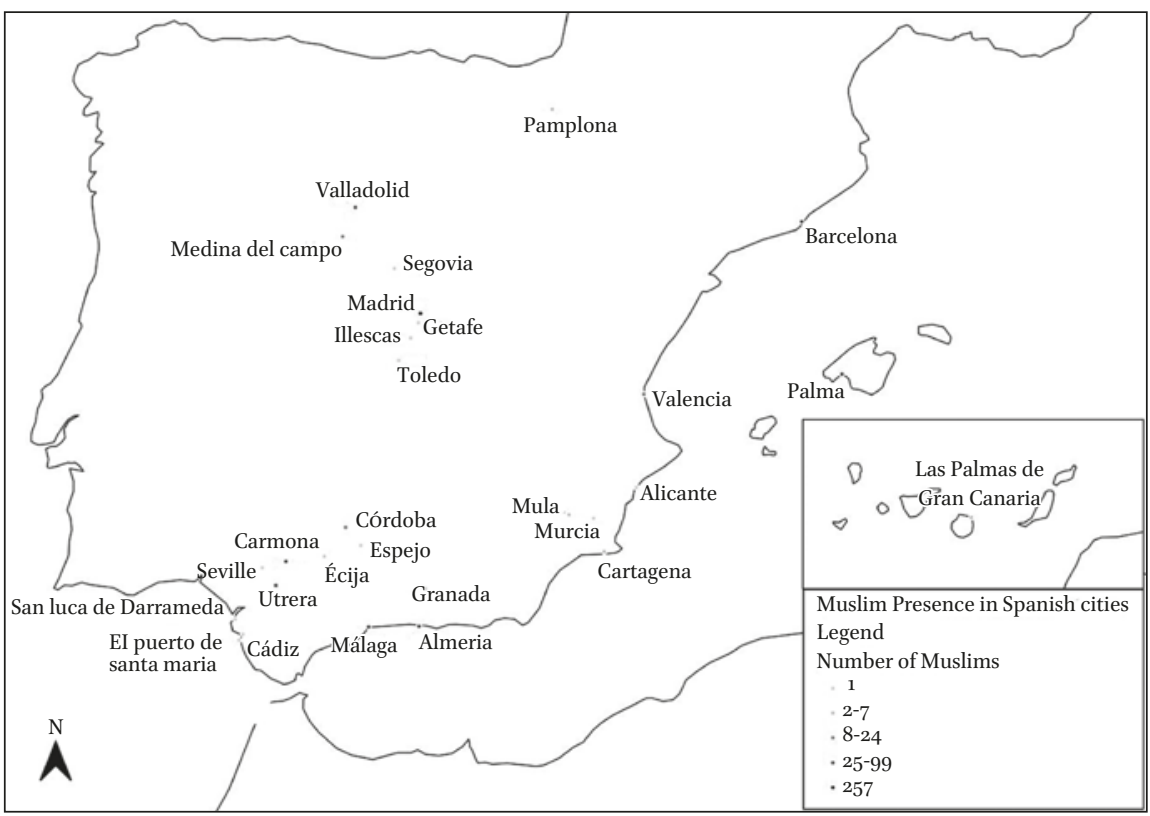

MAP $1 \quad$ Muslim presence in Spanish cities (1492-1767) PREPARED BY ANDREU SEGUÍ BELTRÁN

to $1767 / 1791$. It is merely a preliminary estimate, lacking in many respects, since we do not always know how many members made up the groups that we can identify in documents: retinues of exiled rulers, ambassadors, and emissaries, and groups of people who arrived on Spanish shores in search of a better life.

The map's most notable feature is the central role of Madrid, especially after it was established as the permanent site of the royal Court. Valladolid, Medina del Campo, Segovia, and Toledo appear representing times when the Court was still itinerant. Sanlúcar de Barrameda is probably less prominent than it should be: it was the court of the Duke of Medina Sidonia, the epicenter of Spanish-Moroccan diplomacy from the mid-sixteenth to the seventeenth centuries. Córdoba and Espejo appear because certain governors of the presdidio of Oran received North African envoys there. Las Palmas de Gran Canaria played a similar, though lesser, role with respect to the nearby Saharan coast. Carmona and Utrera were two towns where exiles resided in the sixteenth century. Cádiz, Málaga (and nearby Granada), Cartagena (and the interior of Murcia), Palma de Mallorca, Alicante, Valencia, and Barcelona were all entry ports to the Spanish domains; in the first four there were Muslim colonies during the period under study. And finally, Pamplona in the 
north received a number of Muslims who, having converted, joined the Spanish army and were quartered there.

\subsection{Royal Exiles in the Sixteenth Century: Recover the Throne, or Convert?}

A phenomenon in the sixteenth and seventeenth centuries has received little notice from historians until recently: the existence, in Spain and its Italian dominions of Naples and Sicily, of many Muslims belonging to reigning dynasties of North Africa who had been toppled from their thrones. Once on Spanish soil they sought support and material aid to recover the status lost through internal strife in their homelands. These persons, usually in family groups, were in Alonso Acero's words

rulers in the Islamic societies to which they belonged: monarchs or members of the royal families who determined the destinies of a given kingdom. Their social rank and prior position granted them a swifter welcome and more efficient protection in the Christian world they now entered. Their counterparts, the Christian monarchs, received them and offered them shelter in the face of initial mistrust by the wider society - which, however, eventually celebrated the arrival of such high-ranking Muslims as a moral victory over Islam. These royal exiles were refugees of quality, expected to provide a political benefit in the form of ransoms or alliances; or they might reject their former life and become new Christians, able to occupy distinguished posts in the service of the regime that had welcomed them.

Most of them were monarchs, princes, and other members of the ruling dynasties, often accompanied by their families and partisans: Wattasids and Saadids from Morocco and Fez, Zayyanids from Tlemcen, and Hafsids from Tunis. Alonso Acero stresses that Spanish monarchs behaved well toward these Muslim princes and pretenders, who sought entrance to the Spanish North African presidios or the Peninsula itself: they were

treated as royal personages, [and] welcome was extended to their families, followers, and goods; security and protection was promised by virtue of their social rank. ${ }^{3}$

3 "Fueron cabezas rectoras de las sociedades islámicas a las que pertenecían, como monarcas o miembros de las familias reales que dirigían los destinos de un determindado reino. Su 
As a rule these persons were received by the monarchs, who subsidized their resettlement in Spanish territory. But we must not forget that, just as elsewhere in Europe, Spain considered these exiles to be bargaining chips and hostages of the authorities in advancing their policies toward Muslim countries. Their treatment was a function of whatever relations prevailed with the rulers of Morocco, Algiers, and Tunis.

\subsubsection{Wattasids}

Beginning in the mid-fifteenth century, political life in Morocco was marked by the decadence of the Marinids or "Benimerines" and the rise of popular devotional religious movements. The latter were led by men considered saintly, the morabitos (Arabic murābițūn). Their ascendancy contributed to a fragmentation of power in the region, clashes between cities, and the emergence of Sharifism, the current that sought to rule based on its leaders' prestigious descent from the Prophet Mohammed. The Wattasids (see Figure 1) had been governors or regents under the Marinids, and after adopting the arguments of Sharifism were able to seize power in 1472. Until their replacement by the Saadids in 1554 they managed to rule Morocco in spite of pressure by Portugal, Spain, and the Ottoman Empire, as well as many internal revolts. ${ }^{4}$

In January 1549 the Saadids conquered Fez, the Wattasid capital, and massacred the dynasty's last sultan, Ahmad ibn Muhammad, along with members of his court. A survivor, Abu Hassun ("El Buazón" to Spanish chroniclers) became the head of the deposed dynasty; he had been king of Fez from 1524 to 1526 , then was deposed by his nephew and relegated to the governorship of Vélez. In April 1549, with five followers, he sought refuge in the Spanish presidio of Melilla, where he was later joined by his children and other relatives as

categoría social y posición previas les permitió tener una acogida más rápida y una protección más eficaz dentro del mundo cristiano en el que entraron a vivir. Sus congéneres, los monarcas cristianos, fueron quienes los recibieron y ofrecieron un amparo, frente a la desconfianza inicial de la nueva sociedad, que también acabó por celebrar la llegada de un musulmán de tan alto rango como una gran victoria moral frente al islam. Estos exiliados regios aparecen como tránsfugas de calidad de los que puede esperarse un beneficio político traducido en rescate o alianza, o quizá acaben por renunciar a su mundo anterior y se conviertan en nuevos cristianos que desempeñen puestos destacados al servicio del poder político que los ha acogido. ... [Son] tratados como personas regias, el permiso se extiende a sus familias, séquitos y bienes, respecto a los cuales se establece un compromiso de seguridad y protección en virtud de su categoría social": Alonso Acero, Sultanes de Berbería, 20, 102 .

4 Alonso Acero, España y el Norte de África; García-Arenal and Bunes Ibarra, Los españoles y el Norte de África. 


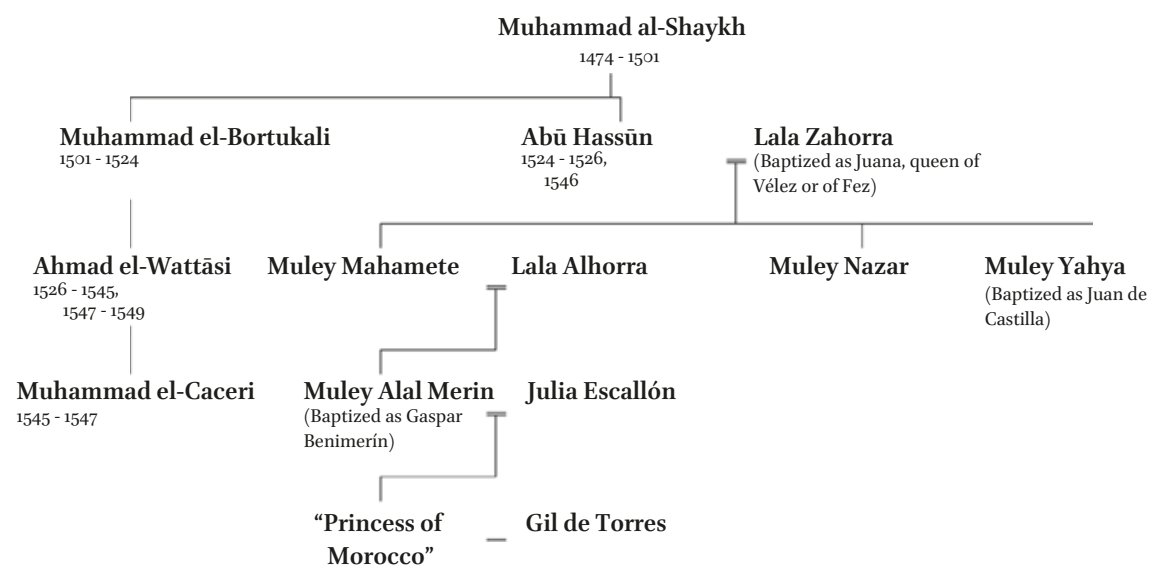

FIGURE 1 Genealogical table of the Wattasids (fifteenth-seventeenth centuries) TABLE BY ANDREU SEGUÍ BELTRÁN. SOURCE: ALONSO ACERO, SULTANES DE BERBERÍA, 90

well as several gentlemen and officers from Vélez. His arrival proved awkward for Melilla: its governor feared the presence of such a large number of faithful Muslims, and the town had few resources to support them.

In spite of his entreaties ("I am alarmed that after I have been in Melilla for so long Your Majesty has not yet decided a matter that so affects your royal service"), Abu Hassun was not allowed to move to Málaga until July. The Captain General of Granada, the Count of Tendilla, considered him "a man much loved and well established who has a strong reputation in Barbary, [so that] it seems to me wasteful to keep him in Melilla." The fact is that while some thought of him as a potential hostage, useful for advancing Spanish interests in North Africa, for others his presence in the Peninsula represented a danger. Abu Hassun asked Charles v to help him regain his throne. Two of his sons, Muley Nazar (alNazir) and Muley Mahamete, accompanied him to Spain, the latter joining his father once he was in Germany. Other companions included Muley Abdallah, "nephew of the king of Vélez," gentlemen, and servants (including two called Abraham and Hamete). In early November Abu Hassun, with an interpreter and ten Muslims (six on horseback and four on foot), left Málaga for Valladolid to meet Maximilian of Austria, the Hapsburg regent. The Moroccan asked for soldiers to help him take Arcila, which the Portuguese wished to leave, and aid "in expelling the [Saadid] Sharif from Fez and the other kingdoms he possesses"; but he was given only a thousand ducats and clothing for his retinue. Having received so little from the regent Abu Hassun decided to go in search of Charles V, who was in central Europe at the time. His party reached Genoa by way of Barcelona on 24 January 1550, and arrived in Brussels in March. They 
did not get much satisfaction from Charles, who had discouraged their journey "because we are so occupied with current affairs." But Abu Hassun remained near the emperor for several months and even took part in fighting the Protestants. Charles assigned him an annuity of 2,40o escudos, plus six hundred for his relatives. During that period more of his family members and partisans arrived in Melilla, and some went on to Málaga and Valladolid. Francisco Verdugo, who was in charge of providing matériel to Melilla, wrote to the regents that

in all the ships of the line that I send to Melilla with mortar and provisions and arms, groups of them will arrive, as they have been doing for some time; and I am heartily sick of them and determined not to receive them in my home, even though I know that on leaving it they will find no one to give them even a jug of water. ${ }^{5}$

Maximilian told Verdugo to make every effort to send the refugees back to their own country, though not at the expense of the royal treasury - suggesting that maintaining Abu Hassun's family and followers had become an economic burden. His sons Muley Nazar and Muley Mahamete had also been receiving fifty ducats a month since June 1550, while in April of that year his nephew Muley Abdallah, "prince of Fez," had been granted seventy-five thousand reales for his expenses in Spain and Portugal. Even the servants, Abraham and Hamete, received ten ducats each, and these amounts were only part of what the Moroccans cost. On 12 July 1551 Abu Hassun and his retinue landed at Barcelona in the train of Prince Philip, who was bound for Valladolid. The monarchy continued to support him, assigning him three thousand ducats a year starting in 1551. In early $1552 \mathrm{Abu}$ Hassun asked the prince for more financial aid and a galleass captained by Álvaro de Bazán for his return to Morocco. Weary of waiting for military help that never came, he moved on to Portugal, where he received a warmer welcome. In January 1554, joined by leaders from Algiers, he defeated Muhammad al-Shaykh al-Mahdi and entered Fez as its conqueror, but in September he lost both the city and his head at the hands of the Saadid sultan. ${ }^{6}$

Some of Abu Hassun's relatives managed to cross into Spain: one was a wife who converted to Christianity and took the name Juana, "queen of Fez";

5 "[E]n todos los navíos que enviare a Melilla con cal e bastimentos e municiones, an de venir cafilas dellos, como hasta aquí lo han hecho; y estoy muy harto dellos e con determinación de no los acoger en mi casa, aunque se que, salidos della, no an de allar quien les de un jarro de agoa": Alonso Acero, Sultanes, 73.

6 Alonso Acero, Sultanes, 66-79; La Véronne, "Lettres inédites," “Politique de Abû Hasûn," and "Princes ouattasides." 
she remains in the records until 1557. Another wife, Lalla Zahorra, arrived in December 1573 to El Peñón de Vélez (in Spanish hands since 1564); she too took the name Juana on her baptism in 1575, styling herself "queen" of Vélez or Fez. She was accompanied by her youngest son, Muley Yahya, and a servant, and all three sought the Catholic monarch's protection and passage to Spain because "the Sharif wished to cut off their heads." ${ }^{7}$ Once in Madrid the mother was determined to join Spanish society, but her son changed his mind and requested economic and military aid to recover the throne in Fez. It was offered to him only as far as Africa; the monarchy, which had funded the family in Spain, sent them on to Portugal where they might enjoy more support, but by the end of the year they were back in Madrid. The "prince of Fez," realizing that he could never reconquer his kingdom, accepted baptism in about 1575 with the name Juan de Castilla. Sent to Navarre with a monthly allowance of twenty ducats, he entered the service of the Viceroy there, and from 1578 to 1592 served in the Spanish army in Flanders, where "he was much esteemed by the Prince of Parma and all the commanders in the field and captains of the army."

A more prominent descendant of Abu Hassun was his grandson (son of $\mathrm{Mu}-$ ley Mahamete) Muley Allal Merin, hastily proclaimed king after his father's death. He left for Spain in the mid-157os but took a roundabout route: landing first in the Cape Verde Islands he fell sick and had a vision of the Virgin, leading him to become a Christian with the name Gaspar de Benimerín. His travels took him on to Madeira, Terceira Island, and Lisbon, and on his arrival in Madrid with a large following he was received by Philip II. (He claimed in a later memoir to have left Morocco in 1570 and have been baptized in Spain.) From 1575 onward he served in the royal armies in several ways: on ships guarding the route to the Indies, on the islands of Santiago and Cape Verde, and in the conquest of Terceira in 1582. Shortly afterward, in Naples, he married and persuaded the Council of Italy to double his monthly allowance. Later on he entered the service of Archduke Albert in Flanders, but was back in Naples at the end of the century; at about that time he asked the king to increase his allowance

because, since he has become a Christian and served Your Majesty, he should be the equal of Don Carlos and Don Felipe, sons of the King of Tunis, who receive one hundred escudos of maintainance a month; and

7 Alonso Acero, Sultanes, 81-84.

8 Alonso Acero, Sultanes, 79-84, 90. 
he should be honored with a religious habit so as to serve Your Majesty better, as he wishes to do.

Between 1604 and 1606 Don Gaspar fought in the war in Hungary, "where his Imperial Majesty favored him with command of a cavalry company."9 At around this time he was deep in debt and had his allowance suspended for a long period. When Morocco grew unstable after the death of Ahmad alMansur in 1603, Don Gaspar wrote to the king offering himself as the only legitimate heir to that throne: "he beseeches Your Majesty to grant him license and authority to use all means possible to recover his kingdom." He promised that he would not do so in detriment of his Christian faith, but for the greater glory of God and the Catholic monarchy. Both he and his uncle Juan de Castilla asked the monarch's leave to contact faithful followers in Morocco who would work on their behalf. In that same year Iuan Vincenzo Scaglione, a relative of Gaspar's wife, dedicated to him his "Origin and Ancestry of the Most Serene Kings the Benimerines, Lords of Africa, down to Don Gaspar Benimerín, Prince of Fez" (Origen y descendenzia de los sereníssimos reyes benimerines señores de Africa hasta la persona del señor don Gaspar Benimerín, infante de Fez). When the Moroccan adventure failed to materialize, in 1612 Gaspar went to defend Greece against the Ottoman menace. In 1618 he founded a new military order, the Milicia Cristiana, with the support of Carlos Gonzaga, Duke of Nevers. On his coat of arms one quadrant displayed a half-moon pointing downward, a symbol of his rejection of Islam. On his death in 1641 he was buried in the church of Santa María de la Concordia in Naples, where his tomb bears a portrait of Emperor Ferdinand III, who proposed his beatification, with a legend asserting his claim to the throne: "Sepulcrum Don Gasparis Benemerini infantis de Fez et ejus familiae de Benemerini." His daughter, known as "the princess of Morocco," married the son of the tutor of pages to Cardinal-Prince Ferdinand of Austria - in a final demonstration of how this converted exile's family was able to rise in Christian society. ${ }^{10}$

There is information about other members of the Wattasid dynasty in Spain, although it is not always precise and sometimes a single individual may appear as two different ones. One Gaspar, "son of the queen of Fez," was implicated in 1555 in a plot in Melilla to free Muslims imprisoned in the presidio.

9 "[P]or venir a ser cristiano y a servido a V.M. lo sea de igualarle con Don Carlos y Don Felipe, hijos del Rey de Tunez, que resciben cien escudos de entretenimiento al mes, y honrarle con un hábito para poder mejor servir a V.M. como dezea hacer": Alonso Acero, Sultanes, 85 .

10 Varriale, "La media luna al revés"; Alonso Acero, Sultanes, 79-88; Viguera, "Noticias sobre el Magreb”; Castries, “Trois princes marocains”; Escallon (Scaglione), Origen y descendencia. 
In 1564 Margaret of Austria, regent of the Low Countries, ordered payment for the travels of two princes: two hundred libras to Don Alonso de Fez, "son of the king of Fez," for a trip to Spain, and the same sum to Don Felipe de Austria, "brother of the king of Morocco," to travel to Germany; the latter was already documented in 1557. Felipe de Aragón, a nephew of the king of Fez, converted to Christianity in Zaragoza around 1553. We know of another Felipe de Aragón seemingly different from the former, "of Moorish lineage, son of the king of Fez, resident in the town of Elche," who may have converted before 1550. In 1563 he approached the Inquisition in Murcia voluntarily, having been accused of being a Muslim, schismatic, and heretic, and of having made pacts with the devil and sheltered heretics. He was sentenced to wear a habit and be confined for three years in a monastery, and "having served them to be exiled from the kingdoms of Aragon, Valencia, and Granada; and having confessed to being a king's son, was sentenced as such." His behavior must have caused great anxiety at a time when tensions with the Moriscos were increasing. ${ }^{11}$

Muley Amar, "king of Debdou" (between Melilla and Fez), arrived in Melilla in July 1550, fleeing the Saadids who had just conquered Tlemcen; his train of relatives and partisans numbered about three hundred. Maximilian of Austria, the regent, feared such a concentration of Muslims in the Spanish town (since Muley Amar's family and followers would join those of Abu Hassun), and ordered that only the king, his family members, and three servants could remain. But Muley Amar protested that "they would prefer to be prisoners of Your Lordship than kings in the hands of the Sharif," so they remained sheltered behind the presidio's fortifications. Muley Amar, who wished to go to court to swear allegiance to Charles v, offered to leave some of his relatives as hostages in Melilla while bringing his sons to fight in the Christians' armies; he hoped to receive the same welcome as Abu Hassun. The religious establishment in Melilla saw a marvelous opportunity to evangelize the refugees. But as the months passed Amar did not receive permission to cross to the Peninsula, and his son-in-law managed to reconquer his kingdom; so when his leave to sail to Málaga was finally granted in March 1551, he had already left Melilla. ${ }^{12}$

\subsubsection{Saadids}

Muhammad al-Shaykh al-Mahdi's rise to power in 1544 brought a period of close alliance with Spain, since both parties wished to resist Ottoman pressure

\footnotetext{
11 Alonso Acero, Sultanes, 88-91.

12 Alonso Acero, Sultanes, 73-76.
} 
on North Africa. ${ }^{13}$ (See Figure 2) His son and successor Abadallah al-Galib began a fierce persecution of other members of his family who might contest his right to the throne. In 1574 Abadallah was succeeded by his son Abu Abdallah Muhammad ibn Abdallah al-Mutawakkil, who had to confront his uncles Abd al-Malik ("El Maluco" in Spanish sources) and Ahmad, who expelled him from Fez and Marrakesh in 1576. After taking refuge in El Peñón de Vélez de la Gomera, al-Mutawakkil crossed to Spain; Philip II promised him aid but, enmeshed in the war in the Low Countries, failed to deliver it. Al-Mutawakkil had better luck in Portugal, where he received the military and economic help he would need to dethrone his uncle Abd al-Malik. The end result was the Battle of the Three Kings at Alcazarquivir in which the Portuguese King Sebastian, Abd al-Malik, and al-Mutawakkil were all killed. ${ }^{14}$

Al-Mutawakkil's son Muley Shaykh (Xeque) was born in 1566. After the disaster at Alcazarquivir he found shelter in Arcila and from there was sent to Lisbon in 1578, with his uncle Muley Nsar (Nazar) and the alcaide Ibn Tuda. They spent ten years in Portugal together with their closest relatives and a large retinue of faithful followers. When Portugal fell to Philip II in 1581 Muley Xeque and his uncle, both with a claim to the throne, became pawns in a three-way game. Philip was negotiating with the ruler of Fez, Ahmad al-Mansur, who in turn sought an alliance with the Portuguese pretender Don Antonio and the English to regain the Portuguese throne. Both uncle and nephew were held hostage to threaten al-Mansur unless he acceded to the interests of the Catholic monarch.

In 1589 both men were taken to Andalusia, where al-Mansur might feel their threat more strongly if Philip decided to support them with money and arms. Muley Xeque, with fifty-seven followers, stayed in Carmona while his uncle resided in Utrera, ${ }^{15}$ both supported by the Portuguese treasury. They soon made contact with Moriscos in both towns, and when those from Carmona conspired with Muley Xeque to free him, he was moved to Andújar in 1593. There he decided to convert and was baptized in the monastery of El Escorial on 3 November 1593, in a ceremony led by the cardinal archbishop of Toledo and with the king and Princess Clara Isabel Eugenia as his godparents. As the newly named Felipe de África or Felipe de Austria he became prominent at

13 La Véronne, "Menaces," "Politique de l'Espagne," and "Política de España."

14 Alonso Acero, Sultanes, 91-92; Valensi, Fables de la mémoire and "Silence, dénegation"; Berthier, La Bataille de l'Oued el Makhazen; Nekrouf, La Bataille des Trois Rois; Bovill, The Battle of Alcazar.

15 The Andalusian towns of Carmona and Utrera were large enough to sustain the expenses of both men with their respective retinues. They had the further advantage of being far from the Spanish court and relatively close to Morocco. 


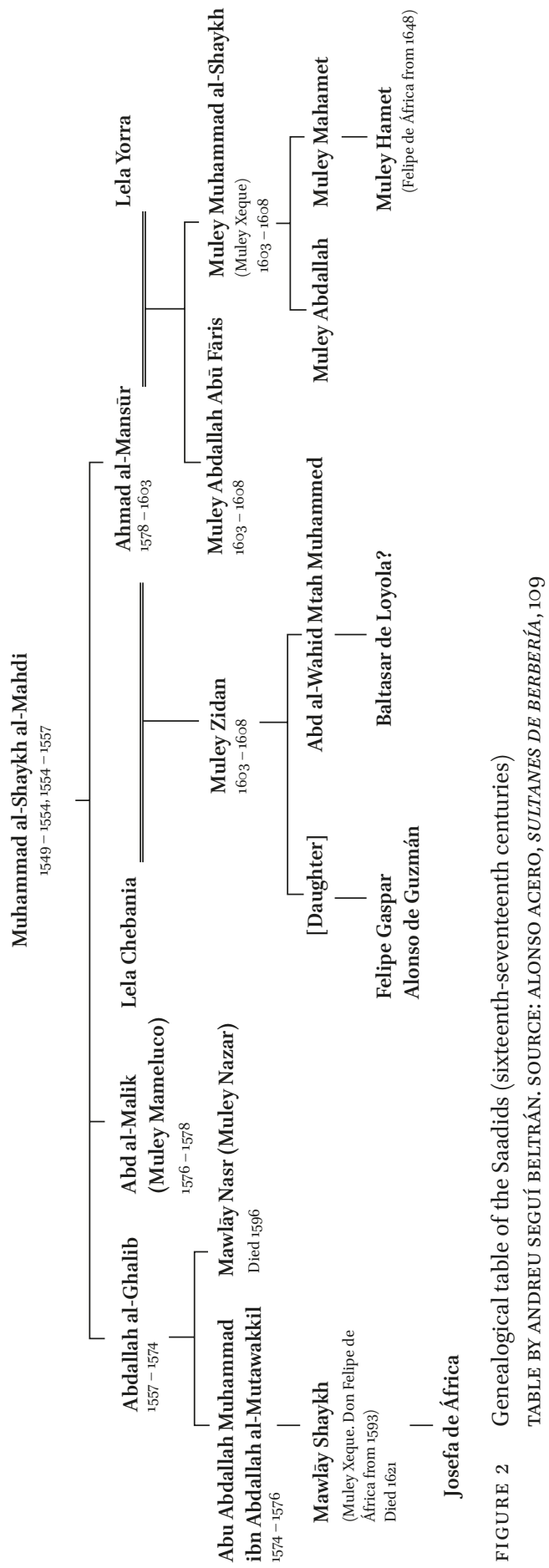


court, since he belonged to a reigning dynasty and had renounced the religion that Spaniards considered false and sectarian. With the title of Grandee of Spain he was ceded the towns of Bedmar and Albanchez in the diocese of Jaén; these paid him rents of twelve thousand ducats a year, to which a thousand more were added for his sustenance. He was made a knight of the Order of Santiago and Captain General of the cavalry of Milan, giving him an exalted military rank.

In 1596 Felipe de África wrote to the Council of the Inquisition requesting that all his descendants be admitted to schools, universities, collegiate churches, cathedrals, the Holy Office, and any other institution governed by the purity-of-blood statutes; thus they would be free of discrimination based on their Muslim origins so long as they remained in the bosom of the Church and had no dealings with "any person with a trace of Moor, Jew, or any other sect in his lineage." The response to this petition shows how much mistrust still existed while the Morisco problem was still alive: "it having been such a short time since the abovenamed received the water of baptism and learned about our Christian religion ... when there are so many descendants of his sect and nation in these kingdoms of Your Majesty, it is right to be very careful of him."16

The prince, who rented rooms in a common residence offered himself in military service to the king to relieve his economic difficulties. The Council of State decided to send him to the war in the Low Countries "because here he is not doing well nor can he benefit anyone, while there he may do some good." Everything indicates that he neither went to Flanders nor received any financial help to do so. In 1609 he was sent to Italy, possibly to keep him away from involvement with Moriscos, whose expulsion had been decreed that year. In Milan he served as a captain of infantry in the war in Piedmont under the command of the city's governor. Retired to a village between Milan and Pavia, and in financial straits because his stipends from the royal treasury failed to arrive, he fell gravely ill and asked to end his days in Spain; but he died a Christian in 1621 before permission was granted. His daughter and heiress, Josefa de África, entered the convent of San Pablo in Zamora. ${ }^{17}$

Muley Nsar, who had also conspired with the Moriscos of Seville and considered himself the only legitimate pretender to the throne after his nephew's

16 Alonso Acero, Sultanes, 95.

17 Alonso Acero, Sultanes, 98-100, and “Los Austrias y el Norte de África." Letters from Muley Xeque to the Spanish monarch in García-Arenal et al., Cartas; La Véronne, "Séjour en Andalousie"; Guastavino Gallent, "Don Felipe de África”; Oliver Asín, Vida de don Felipe de África. 
conversion, returned to Morocco in 1595. In that adventure, lacking any military or economic help from Spain, he lost his life in $1596 .{ }^{18}$

In December 1610 Mahamete ben Muley Nsar appeared before the walls of Oran, claiming to be the son of the deceased Muley Nsar and to have spent fifteen years in prison: "the son of Muley Naçar, the one who spent the last eighteen or twenty years in Spain, who they say was uncle to the prince of Morocco."19 Mahamete was requesting the Spanish king's protection on the grounds that his life was in danger. He sent letters to Don Felipe de África (Muley Xeque) and Philip III, declaring himself the former's cousin. Though some suspected he was an impostor, he was allowed into the fortress on the strength of his desire to convert; he was instructed in the Catholic faith but asked for baptism not in Oran but in Spain. Finally he was allowed to cross to the Peninsula, even though the governor of Oran accused him of being an alchemist, ambitious, and capable of treachery. Arriving in Murcia around March 1611, he came under the protection of Luis Fajardo, commander of the Armada of the Ocean Sea, one of whose assignments was to organize the expulsion of the Moriscos begun in 16og. In December 1611 Mahamete was imprisoned and accused

as a fraud, and that declaring himself a prince was only to give himself importance and thereby to ask His Majesty to grant him some favor, by which to remain in these kingdoms and carry out some ill intent. ${ }^{20}$

It was a delicate moment in the midst of the expulsion of the Moriscos. Presumed an impostor, sent to Oran and imprisoned in one of its castles, Mahamete tried to persuade several soldiers to desert; brought to trial once more in 1612, he was condemned to the galleys. We last hear of him in El Puerto de Santa María, the home base of one of the galley squadrons, where he must still have been a convict rower. ${ }^{21}$

Sultan Al-Mansur of Morocco, at his death in 1603, divided his kingdom among his three sons. Muley Muhammad al-Shaykh (Muley Xeque) received Fez and the Gharb region; Muley Zidan, Tadla and its province; and Abu Faris ("Buferes" in Spanish sources), Marrakesh and its province. When the three

\footnotetext{
18 Alonso Acero, Sultanes, 92, 94; La Véronne, "Séjour en Andalousie."

19 Alonso Acero, Sultanes, 98.

20 " $[\mathrm{P}]$ or embustero e que el aver publicado que era príncipe era solo a fin de acreditarse y por este camino pedir a su magestad le hiciese alguna merced y con ella quedarse en estos reinos y executar algún mal intento": Alonso Acero, Sultanes, 100. 
brothers began to fight for control of the whole country, new waves of exiles arrived in Spain. Muley Muhammad Xeque, yielding to pressure from Muley Zidan, took refuge in Larache, where he sought help from Spain and Italy. Spanish diplomats, eager to seize control of the presidio, soon allowed him to settle in any of Spain's North African fortresses or in the Peninsula, and the king wrote:

I am pleased to grant you that license and security, so that whenever you wish you may come within any of my frontiers or where it suits you best in these my kingdoms, bringing your children, wives, servants, treasures, and jewels.

At the same time he ordered his authorities not to hinder the Moroccan's settlement in Spain:

When the said king arrives in my kingdoms, let him reside in them for as long as he wishes, and I shall order that he be treated and attended as is proper and as his person and estate deserve. ${ }^{22}$

This permission was not immediately needed, however, because Muley Xeque's son made a triumphal entry into Marrakesh in 16o8; but in January 1609 Muley Zidan defeated the son's troops, forcing his brother Abu Faris to flee to Larache. In March, Muley Xeque took advantage of the king's offer and arrived in Portimão in Portugal. Although he asked to go to Madrid to seek Philip III's help in recovering his throne, he was sent instead to Carmona, receiving a warm welcome as he passed through Sanlúcar de Barrameda. Finally, in early July 1609, he settled in Carmona, the same Sevillian town that had welcomed the other Muley Xeque twenty years before, with his mother Lela Horra and some of his followers; the rest were sent on to Utrera so that Carmona would not bear all the costs. Philip III offered him aid in exchange for the fortress of Larache, and Muley Xeque embarked for Morocco in February 1610:

22 "Tengo por bien de concederle la dicha licencia y seguridad, para que cuando fuere su voluntad pueda venir por cualesquier fronteras mias, o por donde más bien le estuviere, a estos dichos mis reynos con sus hijos, mujeres, criados, thesoros y joyas que traxere. ... quando llegare el dicho rey a mis reynos le dexen residir en ellos todo el tiempo que fuere su voluntad, y daré ordenes que sea tratado assistido como es razón y lo mereçe su persona y estado": Alonso Acero, Sultanes, 103. 
On his sendoff Our Lord King gave him many thousands of ducats, many arquebuses, rope, bullets, pikes, powder, six of the king's own horses, and twenty royal tents. And he ordered his commanders of the frontiers and fortresses to give him everything that he might request afterward. ${ }^{23}$

Muley Xeque, arguing that he was forced to leave some of his children in Tangier as hostages, requested a fatwa from the religious men of Fez declaring it licit for him to cede Larache to the Christians. In November, Spanish troops took possession of the town. On this occasion no members of Muley Xeque's family converted to Christianity, though some members of his retinue did: in 1611 three daughters of Hamete Botaybo, "a principal Moor and intimate of King Xeque," were granted 15 o ducats after having been baptized. ${ }^{24}$

Other Saadids went into exile in Spain as well. One was a grandson of $\mathrm{Mu}-$ ley Zidan (the son of one of his daughters), Felipe Gaspar Alonso de Guzmán. After his brother was captured by the governor of La Mamora (modern Mehdya), he offered himself as a hostage in exchange for his brother's freedom; he arrived in Madrid in late 1635 and was received by Gaspar de Guzmán, Duke of Medina Sidonia. A document states that "this Moor from Fez came to Madrid and they want to baptize him and have the King be his godfather." He was baptized in February in the royal chapel of the Alcázar, taking the names of his sponsors, Philip IV and the Count-Duke of Olivares, and of the patriarch Alonso Pérez de Guzmán, who performed the ceremony. He later served under the Marquis of Fuentes in Flanders. ${ }^{25}$

Muley Hamet, a son of Muley Muhammad Xeque and grandson of al-Mansur, was a refugee in Getafe in 1648 and asked protection from Philip IV. A captain of cavalry and infantry, a knight who wore the religious habit of Christ, asked that he be "honored with a decent residence, worthy of a son, nephew, and grandson of so many kings." On 16 October 1648 Muley Hamet was baptized and assumed the name Felipe de África, perhaps because the king had acted as his godfather. Appointed to a post in the royal treasury, he served under arms in Naples. In his correspondence with Pope Innocent $\mathrm{x}$ he signed himself "prince of Fez and Morocco," showing that he did not renounce his origins. ${ }^{26}$

23 "Cuando le despidieron le dio el Rey Nuestro Señor muchos mil ducados, muchos arcabuzes, cuerda, balas, picas, polvora, seis caballos de su persona, y veinte tiendas Reales, y orden a sus Generales de las Fronteras para que todo lo que pidiesse después, y sus Alcaides, le diesse": Alonso Acero, Sultanes, 105.

24 Alonso Acero, Sultanes, 102-05.

25 Alonso Acero, Sultanes, 106.

26 Alonso Acero, Sultanes, 106-07. 
We have mentioned Abd al-Karim Ibn Tuda, of the family that ruled Alcazarquivir, Larache, and Arcila; he had supported his relative al-Mutawakkil, who fell in the Battle of the Three Kings. He reached Lisbon in December 1578 together with Sidi Hammu, the former governor of Meknes, and all their wives, children, and servants. Because he was in financial straits Philip II allowed him to sell some of his personal effects. He was at odds with his nephews Muley Xeque and Muley Nsar. In 1587 we find him in Andalusia but Philip III granted him a return to Morocco in 1598, a journey he made the following year. ${ }^{27}$

\subsubsection{Zayyanids}

In the thirteenth century Yaghmurasan ibn Zayyan, taking advantage of the Almohads' weakness, conquered Tlemcen and founded the Zayyanid dynasty. (See Figure 3) This was the origin of what the Spaniards called the "Kingdom of Tlemcen," whose borders were constantly shifting: it was under constant pressure from its powerful neighbors Tunis to the east and Morocco to the west, which were always trying to seize it. In the early sixteenth century three different actors sought to take control: Spain after it took Oran and Mazalquivir in 1505-1509, the Ottomans after Barbarossa seized Algiers in 1516-1518, and the Saadids from the mid-15oos onward. These conditions explain the fragility of the Zayyanid dynasty, which to fend off the Ottomans and Saadids often turned to Spain; the Spaniards responded by helping its members to regain the throne on several occasions.

Muley al-Nasser al-Thabti (Muley Nazar), son of the king who had ruled Tlemcen from 1521 to 1534, under threat by the Saadids had to seek help from either the Ottomans or the Spaniards. Deciding for the latter, he fled with his family and retinue to Oran and spent several years there without receiving the support he needed for taking back his throne. As we have described above in the case of Melilla, the expenses incurred in hosting these refugees were burdensome for a presidio with few resources of its own. Muley Nazar petitioned the emperor in 1554 for help "so I may recover this kingdom of Tlemcen which belongs to me and is being tyrannized by the Turks, the enemies of all." $\mathrm{He}$ asked specifically for five thousand infantrymen and two hundred cavalrymen, whom he pledged to provision himself. He repeated his plea the following year but the request was never granted. ${ }^{28}$

His brothers Muley Ahmed and Muley Hassan also sought refuge in Oran. One of the latter's sons, whose original name we do not know, grew convinced

27 Cabanelas, "El caíd marroquí 'Abd al-Karim."

28 Alonso Acero, Sultanes, 113-14. 


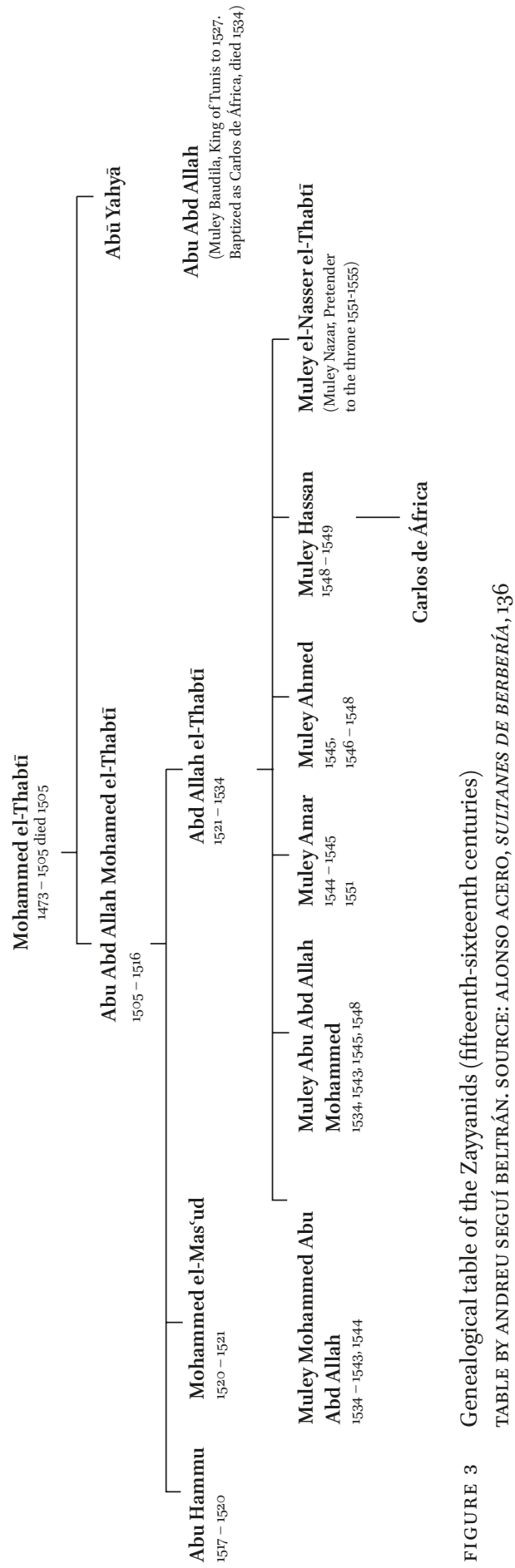


that his dynasty would never recover the throne and converted to Christianity, taking the name Carlos de África. He proved to be the most prominent exile in his family. He remained in Oran until 1565 and reappeared seven years later in Madrid, presenting himself as "Don Carlos de África, the legitimate son of the king of Tlemcen" and lodging in the home of Sebastián Colonna. By 1578 he was captain of an infantry company of ninety-six soldiers in Flanders, earning a monthly allowance of forty escudos. In that same year he petitioned to wear the habit of the Order of Santiago even though he did not fulfill the requirement of purity of blood. ${ }^{29}$ The president of the Council of Orders received a report explaining "who is Don Carlos de África, how he came to receive holy baptism, and how he has served His Majesty in the war in Flanders, so that you may see why he should be favored." ${ }^{30}$ Because the request came from a cristiano nuevo de moro, the Council of Orders was reluctant to grant it and Philip II had to intervene on Don Carlos's behalf:

They tell me that this Don Carlos has conducted himself so well that I have decided to look into his request for a habit; and if it is to be done you would do well to see what facilities need to be given and how the matter should be directed. ${ }^{31}$

The Council remained unconvinced in spite of the royal intervention: "I believe that the habit has never been given to one who descends from the caste of Moors since the establishment [of the order's rules], which exclude them." ${ }^{32}$ In 1579 Philip II issued a royal decree ordering an investigation into Carlos de África's genealogy, and in 1583 the Pope finally issued the dispensation that created the exception for him and gave him the habit. Don Carlos remained in Flanders "until the Spaniards left," then was posted to Oran where he arrived in 1581 , dying in about $1584 .{ }^{33}$

Another Muley Hassan died in Oran around 1551, having arrived there with his wife and son. ${ }^{34}$ In the mid-15oos yet another young man "of the Moorish nation, born in the ancient city of Tlemcen ... of very prominent parents who

29 On this issue see Sicroff, Los estatutos de Limpieza de Sangre.

30 Alonso Acero, Sultanes, 113-14.

31 "Este don Carlos me dizen que se ha governado tan bien que por esto he querido mirar en lo que ha pedido del habito y para si se huviesse de hacer sera bien que miréis que diligencias serian menester y como se havria de encaminar": Alonso Acero, Sultanes, 115-16.

32 Alonso Acero, Sultanes, 116.

33 Tarruell, "Orán y don Carlos de África".

34 Tarruell, "Orán y don Carlos," 283. 
descended from the kings of that kingdom and city" came to Oran. He claimed to have been divinely inspired to convert, and did so: he took the name Martín Formiel after his godfather, the governor of the presidio, who received him into his house. Accompanying his patron on every excursion outside the city, he was captured in Mostaghanem in $155^{8}$ and taken to Algiers. There, after refusing to return to Islam, he died under torture. ${ }^{35}$

Gonzalo Hernández de Córdoba, an interpreter on the frontier, was descended from the Zayyanids through his paternal grandfather. The grandfather, who helped the Spaniards conquer Oran in 1509, married a daughter of the presidio's governor, the Marquis of Comares, and would have become its governor himself had he not died before being baptized. A son of that marriage was Francisco Hernández, who converted to Christianity in his father's lifetime and married a Christian woman from Córdoba. Their son, Gonzalo Hernández, played a crucial role in Spain's negotiations with Muhammad al-Shaykh to mount an offensive against the Ottomans. Gonzalo may have died in the Spanish defeat at Mostaghanem in 1558, an expedition he had strongly supported. ${ }^{36}$

The Zayyanids had their share of false princes as well. A certain Muley Mahamete, who called himself a "descendant of the kings of Tlemcen," appeared in Oran in March 16og. Soliciting Philip III's help in regaining the throne, he claimed support from "the principal men and rulers of the land" and "many other men of Barbary." He received little consideration, perhaps because it had been so long since the Zayyanids' loss of Tlemcen. Muley Mahamete then renounced his claim and offered to serve the Spanish monarch anywhere; he probably needed to earn his living, and preferred not to return to a place where his future was so bleak. A few months later a first cousin of his, "also a pretender to Tlemcen" and a petitioner for assistance, came to Oran as well, but he seems to have fared no better. ${ }^{37}$

The city of Ténès with its province, between Oran and Algiers, was the source of some refugees who sought refuge in Spain; it was ruled by a branch of the Zayyanid dynasty based in Tlemcen. Its early-sixteenth-century leader, Abu Abdallah ("Muley Baudila" to the Spanish), tried to play Spain against the Ottomans in order to stay in power. Dethroned by Khaireddin Barbarossa, he fled to Oran with his younger brother but obtained no help from the governor there. In 1527 we find him with his family and followers in Écija, from where he went on to Málaga to prepare for recovering his throne; although Charles v promised him troops and financial aid they do not seem to have materialized.

\footnotetext{
35 Alonso Acero, Sultanes, 119; Sosa, Diálogo de los mártires, 89-93.

36 Alonso Acero, Sultanes, 119-20.

37 Alonso Acero, Sultanes, 120-22.
} 
Faced with this situation, the siblings converted to Christianity: "this lord of Ténès had himself baptized with his younger brother, and both remained in Spain with a good income from the Emperor." In 1528 Baudila appears as Don Carlos de Tenez living on a royal allowance, presumably until his death in about 1534.38

The Zayyanids held power in Algiers for only a short time. In 15 o1 Selim Ben Thumi proclaimed himself its king, intending to oust the Spaniards who - by controlling El Peñón, an islet in the Bay of Algiers - were interfering with corsair activity from the port. In 1515 he requested help from Aruj Barbarossa, who expelled the defending Spaniards but then took the city for himself and exiled Selim. Cardinal Cisneros, archbishop of Toledo and regent of Spain at the time, needed to prevent Aruj from "putting down roots and growing so much, and so close to Spain"; he assembled a fleet under Diego Vera that attacked Algiers in September 1516. The expedition ended in a disastrous defeat for Spain that only solidified Barbarossa's power over the city. Meanwhile one of Selim's younger sons fled to Oran and was sent to the Peninsula in 1517 in the care of the Cardinal. He converted to Christianity and took the name Carlos de África: "he called himself Don Carlos and was married in Illescas."39

\subsubsection{Hafsids}

We should begin with the province of Bougie which, though it belonged to the kingdom of Tlemcen, was in Hafsid hands from the early sixteenth century. Abu Feres, ruler of Tunis, placed the province under his son Abdulaziz "with the title of king." (See Figure 4)

Shortly before the Spanish conquest of 1510 Abdulaziz's son Muley Abdallah was contesting the throne against his uncle Abderraman. Both sought an alliance with Spain, and to achieve it Abdallah gave his oldest son Hamet as a hostage; his uncle did the same with Mahamet el Blanco, his son with a Christian woman. Both hostages later converted to Christianity: Hamet, also called $\mathrm{Mu}-$ ley Mahomet, was baptized in Majorca and under his new name, Hernando, was known as the "prince of Bougie." He married and had two daughters, one of whom entered the convent of La Concepción de San Francisco in Madrid in 1543. The other, María, was abbess of the Sancti Spiritu convent in Olmedo in 1592. Hernando enjoyed a high standard of living thanks to the five hundred thousand maravedís he was assigned for his lifetime from rents in Cuenca; he owned houses in Mejorada del Campo (Madrid) and had many servants,

38 Alonso Acero, Sultanes, 124-27.

39 Alonso Acero, Sultanes, 124-27. 


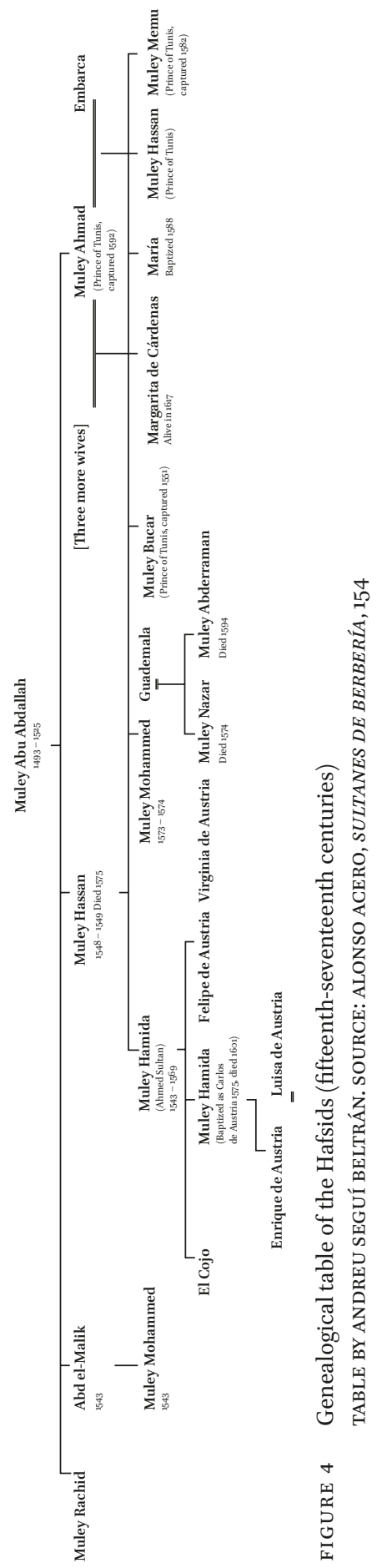


among them several converted slaves like Leonor Gelada de Ambrosio. He died in 1556 or 1557 mourning the loss of Bougie, which had been taken by Salah Reis; he wrote that he had offered unsuccessfully to go to Bougie and form an alliance with his partisans against the Ottomans. ${ }^{40}$

The Hafsids, who had governed Tunis since the thirteenth century, furnished most of the exiles. After the rule of Muley Abu Abdallah (1493-1525), his sons' rivalry for the throne coincided with Spanish-Ottoman competition for control of North Africa. When Muley Hassan emerged victorious his brother Muley Rachid sought an alliance with the Ottomans, who took Tunis in 1534. Muley Hassan then turned to Charles v, whose troops reconquered the kingdom in 1535 and restored him to the throne as the emperor's vassal and dependent. ${ }^{41}$ Always in need of money, Muley Hassan traveled through Italy to Augsburg seeking an audience with Charles, and in his absence his son Hamida proclaimed himself king of Tunis. Returning home at once, Muley Hassan was defeated by his son, who blinded him but left him alive; he managed to return to Europe and even to petition in Augsburg once more. Later he lived in Sicily and Naples, where he probably died in about 1550.

In Sicily Muley Hassan was accompanied by another of his sons, Muley Bucar, who embarked in 1551 in one of the galleys bound for Djerba in an attempt to capture the Ottoman commander Dragut. But his ship was seized and he was taken as a prisoner to Istanbul. The Spanish crown, which was supporting his wife and children, tried to ransom him to show "the barbaric nations that Your Majesty's generosity and benignity extend not only to Christians but to infidels." ${ }^{42}$

An interesting figure in this context was Juana Serafina, "who was daughter to the King of Tunis" - presumably Muley Hassan, who would have entrusted her education to the Spanish. ${ }^{43}$ If that was indeed the case it would show how close relations were between the Spanish Hapsburgs and the reigning dynasties of North Africa. But there is another version of events, possibly apocryphal, about Juana Serafina's arrival in Spain: it claims that she was enslaved in the course of Charles v's conquest of Tunis. An Aragonese noble, Matías de Moncayo, won

from the sack of that city, as happens with armies, a little girl eight or nine years old, daughter of the King of Tunis. As a king's child she had natural

\footnotetext{
$40 \quad$ Alonso Acero, Sultanes, 133-37; Sánchez Ramos, "Don Fernando, infante de Bugía."

41 Boubaker, "Le traité hispano-hafside"; Tellechea Idígoras, "El tesoro de Muley Hacen."

42 Alonso Acero, Sultanes, 139-42.

43 I am grateful to M.A. Bunes Ibarra for this personal communication.
} 
gifts and gallant qualities, and her actions at that age told of her noble lineage. She had a lively wit and tranquil character, and though she was born of Moorish parents she did not care much for their rites: for before the age of six she already discoursed on and doubted some things about the sect of Mohammed that did not conform to her reasoning. And she would ask her father the king or an uncle of hers about them, for he had a rank there that the Moors call "Curitan," which is like a bishop here.

In this telling Moncayo gave the girl as a slave to Ana de Cardona, wife of Juan de Moncada, Count of Aytona, who made her a lady-in-waiting in her palace. The count and his wife tried to persuade her to convert: "'Child', the Countess would say to her, "leave the sect of Mohammed and take the noble step of becoming a Christian.'” As the slave-girl doubted and "was praying most fervently, the Mother of God appeared to her" and pointed the way to the convent: "This is the surest path to Heaven, and the way to enter it is baptism: with this you shall be a beautiful spouse and beloved of my Son Jesus, and will be assured of my protection." At once "her baptism was celebrated with the greatest solemnity and ceremony," and at the age of ten she assumed the name Juana Serafina. It seems that the countess set Serafina free on her death and left her a good dowry. In 1575 she entered the convent of Santa Isabel in Barcelona "with the greatest and most brilliant attendance of the city, and with such an abundance of clothing, furniture, and adornments that the nuns saw many of their needs satisfied." Her life in the convent was not pleasant, however:

There was no lack of times when one [nun] or another abused her with words, calling her "Moor, slave, dog," to which she answered humbly, "I was a Moor, it is true; it is also true that that is my nation, because my parents were Moors; but God through his mercy and goodness took me from that debased state. It is true I should be called a dog .... .and may I be dragged about and scorned so long as I direct my steps toward God." 44

44 "[Al noble aragonés ... le cupo en suerte] del saco que se hizo en aquella Ciudad, porque asi lo pedia el estilo Militar, una Niña, hija del Rey de Tunez, de unos ocho, à nueve años. Como hija del Rey, tenia unas prendas naturales, y gallardas potencias; y sus acciones en aquella edad, dezian quan Noble era su proceder. Era de vivo ingenio, y de genio muy pacifico; y sobre ser nacida de Padres Moros, no le gustavan mucho sus Ritos; porque no teniendo aun seis años, ya discurria, y dudava en algunas cosas de la Secta de Mahoma, que no se le ajustaban a su razón, y las preguntava, ò à su Padre el Rey, ò à un Tio suyo, que allà tenia una Dignidad, que llaman los Moros, Curitan, que corresponde a la de Obispo aqui. ... No faltava otras vezes, que una, ù otra la trataba mal de palabras, diziendola: Mora, Esclava, Perra, à que respondia con humildad: Fui Mora, es verdad; también lo 
Despite all this she became the mother superior of her convent, dying in 1598 .

The Ottomans occupied Tunis in 1569, meeting almost no resistance, and dethroned Hamida; in response Spain retook the city in 1573 and enthroned Muley Muhammad, who had lived in Sicily for several years under the protection of Philip II. Muley Muhammad claimed to have served the Spanish cause for thirty-seven years; in 1559 he had visited Madrid, been received by the king, and obtained a pension of eight hundred escudos to be paid in Sicily, with another three hundred for his son Muley Nazar. In 1574 the Ottomans managed to recapture Tunis and La Goulette, effectively ending the Hafsid dynasty; though some of its members who survived abroad tried to return to power, they were never successful. The new exiles went to nearby Naples and Sicily. In $1574 \mathrm{Mu}-$ ley Muhammad asked the king's help to return to Tunis, believing he would have support from Muslim slaves and Moriscos resident in Naples.

In the meantime Hamida and his partisans were taken to Naples as prisoners, though later they were sent to Sicily and assigned a pension of 850 escudos a year. Hamida too tried to recover the Tunisian throne but died of the plague, leaving a wife and two sons. He bequeathed one of them, called "el Cojo" (the Lame), the bulk of his fortune (eight thousand of his twelve thousand escudos) because of the son's expressed desire to return to North Africa and live as a Muslim. The Viceroy of Sicily made no objection, calling the younger man "lame and of very little substance or drive." The other son, also named Hamida, lived in Naples and wished to be baptized, angering his father and reducing his inheritance to a meager two thousand escudos (the same amount assigned to his mother). In August 1575, only days after the elder Hamida's death, his son adopted Christianity in Naples with the new name Carlos de Austria, having Don John of Austria as his godfather. He asked that his pension be increased from five hundred to 850 escudos a year, since he supported his mother and other relations, but financial troubles followed him all his life. When he enlisted in the Galleys of Naples, the Duke of Sessa commended him to Philip II "bearing in mind the royal blood from which he comes, and the zeal and good will with which he has accepted our holy Catholic faith, and his determination to persist in it." In about 1577 he was in Madrid and seems to have gained the economic support he sought: the Inquisitor General Gaspar de Quiroga was concerned that "he not lose in everything for having become a Christian." Don

es, que lo soy de Nacion; porque mis Padres lo eran; pero sacòme Dios por su misericordia, bondad, de aquel estado de indignación: Es verdad devo ser tratada como Perra; ... y viva yo arrastrada, y entre desprecios, solo que encamine a Dios los passos." There is a chapter devoted to her life ("Vida de la Venerable Sierva de Dios Sor Juana Serafina, hija que fue del rey de Túnez") in Boër, Jardin Mystico, 100-26. 
Carlos placed on his escutcheon a lance between two swords and above them a crescent moon facing downward, signifying that he had abandoned Islam. On his death in 1601 he bequeathed his whole estate to the monastery of Santa María la Nueva in Naples, home to the Minor Friars of the Franciscan order. It seems that he left a son, Enrique de Austria, "grandson of Amida king of Tunez," who was born after his father's conversion and therefore baptized at birth. Enrique lived in Naples on a monthly stipend of 120 escudos that, on his death, passed to his widow Luisa de Austria. ${ }^{45}$

We have notice of a man who claimed to be Carlos de Austria's brother, though the claim is dubious. He lived in Sicily and around 1605-16o6 wrote to Philip III lamenting his financial difficulties; he said he had been baptized under Philip II's reign and had taken Felipe as his baptismal name. His annual pension of one thousand escudos proved insufficient to support himself and his wife, Virginia de Austria, and it was raised to 1,500; but by 1615, with the monarchy struggling financially, it had been reduced to one-third of that amount. ${ }^{46}$

Muley Muhammad, whom the Spaniards had placed on the Tunisian throne in 1573-1574, had an eldest son named Muley Nazar who had lived in Sicily and died in battle in Tunis. Another son, Muley Abderraman, was in Palermo in 1574 and wished to travel to the court in Madrid to swear fealty to Philip II in his father's name, but the monarch ordered him to remain where he was, in charge of his father's three wives, his brother's two, and a good number of servants. He therefore asked in 1575 and 1577 for an increase in his annual pension from five hundred escudos to the 1,250 assigned to his father and his elder brother. Muley Abderraman did not give up his claim to the throne: he tried to attract partisans in Tunis, taking advantage of a period of Ottoman weakness in the region. In 1594, claiming to be supported by several sheikhs and morabitos and to have more than sixty thousand followers, he asked the Viceroy of Sicily to provide fifty or sixty galleys for an assault on Tunis. The wary Viceroy spoke of "the little credit one can place on promises by Moors; this subject seems to me lacking in strength and ill suited to having any edifice built upon him." Muley Muhammad died later in 1594, ending the already faint hope that any branch of the Hafsids might return to power in Tunis. ${ }^{47}$

Another Hafsid, Muley Ahmed, was a son of Muley Abu Abdallah and a brother of Muley Hassan; he had lived in Sicily since childhood, during the rules of Muley Hassan and Muley Hamida. In 1570 he offered himself to Philip

\footnotetext{
45 Alonso Acero, Sultanes, 142-46; Monchicourt, "Études kairouanaises."

46 Alonso Acero, Sultanes, 146-47.

47 Alonso Acero, Sultanes, 148-49.
} 
II as the ideal candidate for expelling the Turks from Tunis: "because of his ancestry and because he has been called, he has a right to the throne." He asked for assistance on the grounds of his thirty years' service to the monarchy, offering his four wives and seven children in Sicily as potential hostages. He proposed founding a Muslim kingdom that would be a vassal state of the Christians - not a new idea in Spain's North African policy. It was a difficult period for Spain (there were problems with Portugal and Flanders, and a truce with the Ottomans), causing Philip II to delay the requested military aid, which never materialized. Nonetheless Muley Ahmed proceeded with his attempt at the throne in 1581. In 1579 he had already sent his eldest son Muley Memu to the Spanish court to present his respects to the monarchy and solicit help; Philip II approved the operation in principle, though without offering any material aid. The expedition sailed for Carthage in the spring of 1581, but failed. Muley Ahmed managed to remain concealed in the Tunisian hinterland until 1592, when he was captured by Ottoman troops; his son Muley Memu had already been taken, and both were conveyed to Constantinople where they ended their days in prison. ${ }^{48}$

In 1592 one of Muley Ahmed's descendants, Muley Hassan, wrote to Philip II requesting support for himself and his family members in Sicily. One of his sisters had been baptized in 1588 in the chapel of Palermo's royal palace, taking the name María and with the Viceroy as her godfather. In 1595 help was requested for two other Tunisian princesses exiled in Palermo. Three wives of Muley Ahmed, who had been captured in Tunis in 1582, were left in the care of Muley Hassan; one of them, named Embarca, had a son. Guademala was a wife of Muley Muhammad, the ruler deposed in 1574; she had lost a son in Tunis and had a granddaughter in her charge. And another wife of Muley Ahmed's, whose name is unknown, lived in Palermo with an unmarried daughter. ${ }^{49}$

Not only members of the royal families but members of their retinues, sometimes of distinguished lineage, lived in European exile. Some descendants of Sheikh Abdallah Benegerio (or Ben Ajaria) were held hostage by the Spanish in place of Muley Ahmed himself. Benegerio's son Francisco Pérez de Vargas converted and settled in La Goulette; captured in the defeat at Djerba in 1560, he was taken as a prisoner first to Istanbul and then to Tunis. He escaped and returned to La Goulette, and when that fortress was captured in 1574 moved to Sicily, where he joined Muley Ahmed's circle. His son Aníbal Vargas entered military service under the Hapsburgs, always in Sicily. Aloisa de Sarmiento, a

48 Alonso Acero, Sultanes, 149-51.

49 Alonso Acero, Sultanes, 151. 
sister of Francisco Pérez de Vargas, also lived in Sicily from 1574 and married Juan Sarmiento, an exile from Kairouan who converted to Christianity. Their son also entered the king's service. ${ }^{50}$

We conclude this section by noting some of the violent incidents provoked by members of these exile groups, of which the largest number were associated with Muley Xeque's retinue. On their passage through Alcalá de Guadaira one man was accused of stabbing a crucifix ("he outraged a cross that they met along the way"), and while Muley Xeque wanted to have him executed he handed him over to the local authorities instead, claiming a reluctance to spill blood within the king's domains. The king's representative who accompanied him, Joanetin Mortara, thought that Muley Xeque should "act in punishing his people as if he were in his own realms, and the Moors' situation requires no less than how their kings usually act with them." The Asistente (magistrate) of Seville, not knowing how to proceed, asked for instructions from the king, and in the end it was ruled that the accusation was false. ${ }^{51}$ For the Duke of Medina Sidonia, a different problem was "the impertinent and excessive things they demand, especially the queen mother, as to being regularly entertained, as freely as if this were their right." In Carmona, one of the towns where the exiles were lodged, the royal magistrate asked the king to reimburse their expenses from the royal treasury, since they were so burdensome to the local economy. The cardinal of Toledo thought that "no one should force anyone else to lend what he does not have; and if this would be unauthorized and indecent in the case of native people it is much more so for Moors, who will observe it and take note. 52

\subsection{Exile in the Seventeenth and Eighteenth Centuries: Saving One's Life above All}

The flow of exiles from North Africa to Spain continued in the seventeenth and eighteenth centuries, but it had changed a great deal since the 1500 . With a few exceptions it no longer consisted of members of dethroned dynasties who sought help in returning home and retaking power; now there were individuals who, though distinguished in their own countries, had no path to power or influence but might be fleeing persecution. The consolidation of the Ottoman Empire on the one hand, and that of the Saadid dynasty on the other, explain

\footnotetext{
$50 \quad$ Tarruell, "Circulations," 97.

51 García-Arenal et al., Cartas, 96.

$5^{2}$ García-Arenal el al., Cartas, 101.
} 
the changed composition of the exile community. But the new immigrants also included members of tribal factions, families, and individuals who were fleeing either some kind of reprisal or desperate living conditions.

The rule of the Saadids (1554-1569) and the later accession of the Alawites favored Morocco's consolidation as a unitary state; from then on it was better able to confront, with more or less success, interference by the Ottomans and the Spanish into different pretenders' struggles for the throne. ${ }^{53}$ At the same time the Ottomans' complete dominion over Algiers, Tripoli, and Tunis from 1574 onward limited Spanish influence in the region enormously, since that influence had rested on supporting local dynasties that opposed the Sublime Porte. ${ }^{54}$

In this later period the bulk of the exiles were individuals or small family groups who fled North Africa in fear for their lives, or intending to make a clean break with their former world. For this reason they left fewer documentary traces, and information about them may be scattered in local archives that are difficult to locate.

Some of these individuals left the Maghreb in the sixteenth century. In 1575 the governor of Oran, Diego Fernández de Córdoba, sent to the court an alcaide from Mostaghanem who took the name Felipe Hernández de Córdoba on baptism. Eager to serve the monarchy, he was sent to the Viceroy of Navarre with a salary from the royal treasury.

In 1594 a Sicilian slave brought the authorities a series of letters, including two signed by Philip II in 1561 and 1565; the king acknowledged learning that Mali Mustafa, "chief artillery founder to the King of Algiers," wished to convert to Christianity. Mustafa was asking for royal help but he died without ever receiving it. After his daughter Sultana or Soldana had bought the Sicilian's freedom he gave her the letters to present to the Spanish court. The matter was discussed and eventually decided in Sultana's favor: according to a notation made in 1603 , she reached Spain and became a Christian. ${ }^{55}$

In 1598 the Council of Italy discussed what allowance to give to Dorotea Blanquete or Bianqueta, a daughter of "Mahomet Bassa" (Muhammad Pasha). She claimed that her father had been Beylerbey of Algiers in 1567-1568 and was descended from the famous Salah Reis. Dorotea placed herself "under the shelter and shadow of Your Majesty, leaving her former error and taking the water [of baptism]." Her mother Victoria Sultana, who was making the same petition,

53 García-Arenal, Ahmad al-Mansur; Mouline, Le Califat imaginaire.

54 Merouche, Recherches sur l'Algérie; Guellouz et al., Histoire Générale de la Tunisie, vol. 3; Manca, Il modello di sviluppo economico.

Alonso Acero, Sultanes, 128-29. 
reported that as they were traveling in a galliot the passengers rebelled with the help of a renegade, seized the ship, and managed to reach Crete. Victoria was traveling with her five children, ten ladies-in-waiting, and six female servants, all of whom were baptized in Crete. She asked the monarch for a sum of money to be dispensed to her in Milan. ${ }^{56}$

At about the same time a second Dorotea Bianqueta, different from the first, appeared, accompanied by her mother Ana Mena. They claimed to be the daughter and wife of Amato Pasha, Beylerbey of Algiers from 1586 to 1589, the year of his death in Tripoli. With the monarch's permission they sailed from Italy to Spain. Ana Mena died soon after landing in Barcelona in 1594, and the daughter entered the convent of Santa Catalina in Madrid. ${ }^{57}$

The so-called Kingdom of Kuku, in the Kabylia region, sought an alliance with Spain for several years as it tried to shake off the yoke of Ottoman Algiers, and the resulting struggles produced a number of exiles. Early in the seventeenth century a family descended from the "lords of Kabylia" converted to Christianity and moved to Spain's Italian dominions. Its most prominent member was Felipe de Cárdenas, who had clearly taken his surname from the Viceroy of Sicily between 1598 and 1601. He arrived on the island with his daughters: one, Dorotea de Austria, is documented in 1613. Another, Ana de Cárdenas, "of Moorish origin from among the principal persons of Barbary and lords of Kabylia," petitioned in 1646 for aid in securing the economic future of her daughters, born of her union with an army captain. ${ }^{58}$

An ambassador from the king of Kuku converted to Christianity in Oran, adopting the name Luis de Aguilar. In 1611 the Council of War awarded him an annual pension drawn on the funds of the royal armada. ${ }^{59}$

A prominent figure was Mahamet Chelebi or Felipe de África (1627-1686), whose life between the Muslim and Christian worlds makes him an emblematic "man of the frontier." He was the eldest son of the Bey of Tunis, Ahmad Khuja; at the age of sixteen he expressed a desire to turn Christian, and learned Italian from some of his father's slaves. When he set to sea with several Christian captives in 1646 his ship was attacked by the Knights of Malta, but they managed to reach the port of Mazara in Sicily, where the bishop welcomed him. He was catechized in Palermo and baptized in a ceremony led the the archbishop, with the Viceroy and Vicereine as his godparents, receiving the names Inocencio Felipe Pedro Ignacio. He was admired for his naval experience:

56 Alonso Acero, Sultanes, 129-31.

57 Alonso Acero, Sultanes, 131.

58 Alonso Acero, Sultanes, 133.

59 Alonso Acero, Sultanes, $132-33$. 
This Turk is a man of great good luck and talent ... he is of a proud nature and very skilled in every activity of a knight, and those who come with him affirm that for three years he has led the galleys of Bizerte as their admiral. ${ }^{60}$

After his baptism Felipe was assigned a stipend of one hundred escudos a month, and the king was informed of the "inclination he showed toward the religion of Saint John, wishing to adhere to the great Cross." He visited Naples and was received in Rome by the Pope, then moved to Spain where he married a Christian woman and lived in Cádiz and Málaga (where his mother traveled from Tunis to visit him). But he did not wish to renounce his supposed rights as prince of Tunis (he styled himself "son of the King of Tunis"), though in fact he had none, since the office of Bey of the Regency was not hereditary but appointed from Istanbul. Disappointed in his plans, he returned to North Africa and to the Islamic faith in 1649 - though he always claimed it was only to save his life, his ship having been captured by corsairs. By 1656 he professed Christianity once more and sought to convert Tunis to that religion, recover La Goulette, and place the whole kingdom under Philip Iv's protection. Ignored, he made the same proposals to Louis XIV in 1670 but met with no more success. Again he became a Muslim, engaged in political intrigue in Tunis, and was sent as ambassador from the Dey of Algiers to Istanbul, where he was appointed Pasha of Algiers; but he died of plague before he could take up that long-desired post, having lost all his good credit in the Christian world. ${ }^{61}$

Sheikh Ali of Tunis and his son, who must have been refugees in Palermo since the Ottoman conquest of the previous century, were baptized between 1611 and 1615 and godfathered by the Viceroy of Sicily. Ali had been assigned fifteen escudos before his conversion, causing his fourteen-year-old son Pedro Girón to ask to inherit the stipend after his father's death. At around the same time we find mention of María Girón, "of Moorish origin and a descendant of the kingdoms of Tunis," who protested that her stipend of seven escudos had been reduced by two-thirds. ${ }^{62}$

6o "Este Turco es hombre de buena suerte y muy buen talento. ... es de condición altivo y tiene mucha agilidad en todas las acciones de Cavallero, y los que vienen con el han afirmado que tres años continuos ha gobernado las galeras de Viserta como general de ellas": Alonso Acero, Sultanes, 153 .

61 Alonso Acero, Sultanes, 152-55; Grandchamp, "La fuite de Tunis"; Grandchamp and Bacquencourt, "Documents divers concernant Don Philippe”; Bonnery, "Un homme entre deux mondes." 
In ${ }_{1671}$ Prince Muley Larbe Xerife was baptized in Seville, taking the name Agustín. In Cádiz he preached to his former coreligionists, trying to persuade them to embrace Christianity. ${ }^{63}$

In the eighteenth century, the most prominent group of exiles consisted of Algerians from the vicinity of the Spanish presidio of Oran who joined the Spaniards as allies: they took up arms against their fellow Muslims and protected the Spanish garrisons against them. They were known as "Moors of peace," "free Moors," or Mogataces. ${ }^{64}$ On Spain's loss of Oran in 1708 some of them embarked with surviving Spanish troops and were sent provisionally to Málaga. We find one of them in documents of the time: Musa Bandar, "the Sheikh of Ifre, one of the places subject to our Lord the King," was living in Málaga in 1716. In November of that year he gave a power of attorney to Lesmes García Sagredo, "Secretary to Your Majesty and to the most excellent Señor Don Carlos Cassas, Captain General of these coasts," to present and defend his petitions to the king and the Council of Castile. The document, dated 16 November, was signed by a witness because Musa did not know "our Castilian language."65

After Spain reconquered Oran in 1732 the "Moors of peace" returned home. But when Spain left it for good in 1792 a number of Mogataces left with them, settling in Ceuta. In time they formed the nucleus of the Moorish Sharpshooters (Moros Tiradores) of the Rif and of the Volunteer Militia of Ceuta, which eventually fused with units of regular troops that were made up of Muslims (and a few Spaniards) under Spanish officers. ${ }^{66}$

Spain had shown its most intolerant face, as well as its fear, toward thousands of Moriscos and slaves; but at the same time it proved more open toward thousands of Muslims who sought refuge on Spanish soil. Many who fled North Africa found safety there and felt that their lives had been saved. Among them were dethroned members of the reigning dynasties who escaped from their own countries and hoped - often without success - to find political, military, and financial aid in Spain. Some of them, eventually convinced that their

63 Vincent, "Musulmans et conversions”/“Musulmanes y conversión.”

64 Mesa Gutiérrez, De los Mogataces; Maíllo Salgado, "The Almogataces"; Arqués and Gispert, Los mogataces; Bodin, "Notes sur l'origine du nom de 'Mogatazes."

65 Archivo Histórico Provincial de Málaga, Protocolos (scribe Francisco Caballero Corbalán), fol. 714 .

66 Mesa Gutiérrez, De los Mogataces; Maíllo Salgado, "The Almogataces"; Arqués and Gispert, Los mogataces. 
thrones were lost for good, decided to remain in Spanish territory, and most but not all of those accepted Christianity. The ones who chose to return to Morocco, Algeria, or Tunis to recover their thrones almost invariably lost their lives in the attempt. Everything indicates that no other European country experienced a similar flood of Muslim exiles, with the natural exceptions of the Spanish dominions in Italy (Naples, Sicily, and to a lesser degree Sardinia), Portugal (especially when it was ruled by the Hapsburgs), and perhaps lands under the rule of the Austrian Hapsburg branch.

There is a paradox here: in the European lands supposedly devoted to a crusade against the infidel, Muslims who were in difficulties in North Africa found shelter more readily than in countries that had made alliances and treaties with the Ottoman Empire and Morocco. It proved easier for Muslims to find protection or a means of subsistence in Spain than in that other, more pragmatic Europe, less imbued with the epic of a crusade but much less inclined to accept tens of thousands of Muslims, converted or not. 